\title{
Universities seek to boost industry partnerships
}

\section{As drug companies shift focus, academia ramps up its role in bringing discoveries to market.}

\section{BY ERIKA CHECK HAYDEN}

W hen Matthew Shair discovered a protein involved in causing blood cancer - and a small molecule that might disrupt that protein - he saw the makings of a new drug. Facing years of costly work to prove its worth, Shair, a chemist at Harvard University in Cambridge, Massachusetts, did not seek funding from the usual sources, pharmaceutical companies and venture-capital firms. Instead, in 2012, he turned to a Harvard programme that supports preclinical research. It provided him with US $\$ 250,000$ for preliminary studies in mice and human cells, to determine whether his drug justified undergoing clinical trials.

"It gave us the freedom to do the experiments the way we wanted to do them, rather than the way a company might think we should do them," he says. His experience may soon become more commonplace. Faced with the increasing reluctance of drug and venturecapital firms to fund early development work, academic institutions worldwide are seeking ways to support research that can transform a promising discovery into a marketable therapy (see 'Capital crunch').

Funding for early drug-development research has increased over the past year. In April 2013, a \$50-million donation quintupled the size of Harvard's preclinical programme, which aims to turn a profit and invest that in more grants. And the University of Oxford, UK, last month launched a $£ 1.25$-million (US\$2 million) development fund that allows private investors to support the commercialization of discoveries through its businessdevelopment unit, Isis Innovation.

Hybrid academic-industrial drug-development schemes are also on the increase. The Karolinska Institute in Stockholm is set to open a $\$ 100$-million translational research centre funded by London-based drug firm AstraZeneca in July. A partnership between New York's Memorial Sloan Kettering Cancer Center, Rockefeller University and Weill Cornell Medical College launched the \$20-million Tri-Institutional Therapeutics Discovery Institute (Tri-I TDI), together with Takeda of Osaka, Japan, in October. And last month, the Scripps Research Institute in La Jolla, California, announced that Johnson \& Johnson of

\section{CAPITAL CRUNCH}

US venture-capital funding for life sciences has stayed relatively flat over the past decade. In response, universities have developed new funding models to transform discoveries into marketable therapies.

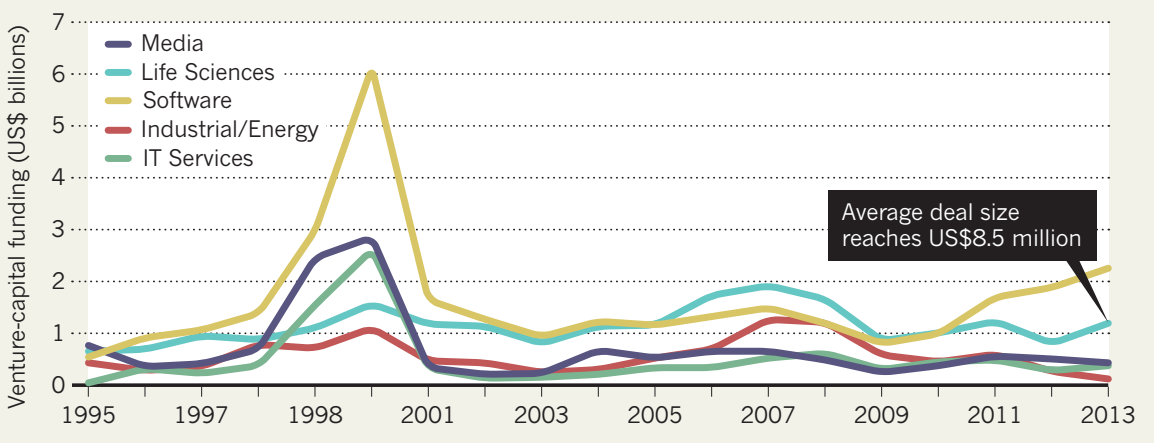

New Brunswick, New Jersey, would be the first industry partner for its new 'Scripps Advance' drug-discovery institute.

Drug companies and research institutes hope that the new programmes will kill two birds with one stone: replenish the pharmaceutical industry's depleted pipeline of new drugs, and bring money to institutions that face shrinking public funding. "The more quality shots on goal you have, the more quality you get in terms of revenue," says Scott Forrest, vice-president for business development at Scripps.

Backers of the programmes also hope to avoid the pitfalls that stymied the most recent wave of academic-industrial partnerships in the 2000s. Drug companies outsourced early drug-discovery work to academic researchers,

"We're seeing a drying up of the basic-research enterprise, which is going to create aproblem."

often did not synchronize with industrial goals.

The latest partnerships are more focused: they explicitly funnel academic creativity into the pursuit of new therapies. Tri-I TDI, for example, aims to find drugs including those for diseases that industry has eschewed because they are unlikely to generate large profits, such as neglected tropical diseases and rare cancers. Projects will be selected by academic scientists and carried out by Takeda's scientists at the Tri-I TDI partners' facilities in Manhattan. "No one gets to veto a project because it isn't the right market size," says David Scheinberg, chair of Memorial Sloan Kettering's experimental therapeutics centre and a Tri-I TDI board member.

Work at the AstraZeneca-Karolinska centre, meanwhile, is geared towards cardiovascular and metabolic diseases, such as diabetes. The venture is recruiting academic researchers to work alongside AstraZeneca scientists. "We really want to make new discoveries here that, in turn, could eventually possibly be druggable," says Hans-Gustaf Ljunggren, the Karolinska's dean of research.

But such arrangements are still vulnerable to market forces. On 2 May, a bid by New Yorkbased drug firm Pfizer to buy AstraZeneca was rebuffed by the company. However, it is not clear how the Karolinska centre would be affected should such a merger eventually go ahead. More broadly, some observers note that if academics and funders continue to shift towards more applied work, there is the risk of a void being created in the basic research that underlies the quest for new therapeutics. Even key funding agencies such as the US National Institutes of Health are shifting towards more translational research. "We're seeing a drying up of the basic-research enterprise, which is going to create a problem," says Kenneth Kaitin, director of the Tufts Center for the Study of Drug Development in Boston, Massachusetts.

To many institutions, and to young scientists such as Shair, shaping the development of their discoveries has become even more crucial at a time of scarce resources. "I love having a foot in both sides," he says. "This is part of the future." 